\title{
Terapi Behavioral Dengan Teknik Desensitisasi untuk Mengatasi Kecemasan dalam Menyelesaikan Masalah Matematika
}

\author{
Sri Fuji Astuty ${ }^{1}$, Widodo Winarso ${ }^{1 *}$ \\ 1. Jurusan Tadris Matematika, Fakultas Ilmu Tarbiyah dan Keguruan IAIN Syekh Nurjati Cirebon \\ *e-mail: widodoiain@gmail.com \\ (Received: 05-05-2021; Reviewed: 17-09-2021; Accepted: 23-09-2021)
}

\begin{abstract}
Abstrak
Fenomena kecemasan dalam penyelesaian matematika dikalangan siswa kerap terjadi, namun penyelesaian permasalahan tersebut belum banyak menjadi perhatian para guru matematika. Penelitian ini bertujuan mengatasi kecemasan siswa dalam menyelesaikan masalah matematika dengan menerapkan terapi behavioral menggunakan teknik desensitisasi sistematis sebagai upaya penangananya. Metode yang digunakan dalam penelitian ini adalah kualitatif dengan desain penelitian studi kasus. Adapun instrumen yang digunakan dalam penelitian ini yakni skala kecemasan menggunakan skala T-MAS, wawancara dan dokumentasi. Penelitian dilakukan pada 25 siswa kelas X AKL-1 SMK Islamic Centre Cirebon. Tiga tahapan analsisi data yang terdiri reduction, display dan conclusion drawing atau verification dilakukan dalam penelitian ini. Adapun hasil penelitian ini mendapati 3 siswa yang tidak mengalami kecemasan, 5 siswa yang mengalami kecemasan ringan, 12 siswa mengalami kecemasan sedang, 4 siswa mengalami kecemasan berat dan 1 siswa mengalami kecemasan panik. Sedangkan terdapat 9 tahapan dalam terapi yakni pengkondisian, rasionalisasi, latihan relaksasi, menyusun hierarki, diskusi gambaran hal yang menyenangkan bagi konseli, relaksasi, memunculkan hierarki kecemasan dan mengamatinya serta melakukan evaluasi tindakan. Selanjutnya, berpedoman pada standar uji perilaku tingkat keberhasilan penerapan terapi behavioral dengan teknik desensitisasi sistematis menunjukkan persentase $66 \%$ gejala tidak pernah dilakukan seperti posisi duduk yang gelisah dan tangan yang berkeringat dimana $60 \%<x<75 \%$ dikategorikan cukup berhasil. Sehingga terapi behavioral dengan teknik teknik desensitisasi sistematis berimplikasi dalam menurunkan tingkat kecemasan siswa dalam penyelesain matematika.
\end{abstract}

Kata Kunci: Kecemasan, Penyelesaian Masalah Matematika, Terapi behavioral, Teknik Desensitisasi Sistematis.

\begin{abstract}
The phenomenon of anxiety in solving mathematics among students often occurs, but solving these problems has not received much attention from mathematics teachers. This study aims to overcome student anxiety in solving mathematical problems by applying behavioral therapy using systematic desensitization techniques to deal with it. The method used in this research is qualitative with a case study research design. The instrument used in this study is the anxiety scale using the T-MAS scale, interviews, and documentation. The study was conducted on 25 students of class X AKL-1 SMK Islamic Center Cirebon. Three stages of data analysis consisting of reduction, display, and conclusion drawing or verification were carried out in this study. This study found that three students did not experience anxiety, five students experienced mild anxiety, 12 students experienced moderate anxiety, four students experienced severe anxiety, and one student experienced panic anxiety. At the same time, there are nine stages in therapy: conditioning, rationalization, relaxation exercises, compiling a hierarchy, discussing pictures of fun things for the counselee, relaxation, raising the scale of anxiety, and observing it and evaluating actions. Furthermore, based on the behavioral test standard, the success rate of implementing behavioral therapy with systematic desensitization techniques showed a percentage of $66 \%$ of symptoms that had never been done, such as a restless sitting position and sweaty hands where $60 \%<x<75 \%$ was categorized as quite successful. So that behavioral therapy with systematic desensitization techniques has implications for reducing students' anxiety levels in solving mathematics.
\end{abstract}

Keywords : Anxiety, Mathematical ProblemSolving, Behavior Therapy, Systematic Desensitization. 


\section{PENDAHULUAN}

Pada mata pelajaran matematika, pemecahan masalah merupakan aspek utama dalam kurikulum yang dibutuhkan siswa untuk menerapkan, mengintegrasikan banyak konsep dan keterampilan matematika serta membuat keputusan yang sangat penting untuk pengembangan pemahaman konseptual (Tarzimah, Tambychika \& Meerah, 2010), sehingga melalui pembelajaran matematika diharapkan mampu memberikan dampak kepada siswa terkait pengembangan nalar, berpikir logis, sistematis, kritis, cermat, dan bersikap objektif serta terbukti dalam menghadapi permasalahan terutama dalam kemampuan penyelesaian masalah (Novaliyosi, 2018; Noordyana, 2016). Namun, banyak siswa yang tidak tertarik dengan matematika dan seringkali mempertanyakan relevansi dari banyaknya waktu yang dihabiskan untuk pelajaran ini (Andersson, Valero, \& Meaney, 2015; Winarso \& Yuliyanti, 2017).

Berdasarkan hasil survei TIMSS (Trends in International Mathematics and Science Study) menunjukkan bahwa nilai kemampuan siswa Indonesia dalam pembelajaran matematika di bawah nilai rata-rata international. Hasil survei TIMSS tahun 2015 yang dicapai siswa Indonesia berada pada urutan ke 44 dari 49 negara dengan poin 397 (McComas, 2014). Sementara Central Connection State University asal Amerika Serikat, telah merilis hasil penelitian menggunakan variabel PIRLS dan PISA mengenai World's Most Literate Nation Ranked pada Maret 2016 yang menyatakan Indonesia pada peringkat ke 60 dari 61 Negara (Fauziah \& Lestari, 2018). Selain itu, hasil pembelajaran matemtika masih tergolong rendah terutama dalam hal kemampuan memecahkan masalah matematis. Dari data yang diperoleh, sebanyak $73 \%$ siswa masih memiliki kemampuan pemecahan masalah yang relatif kurang (Sumartini, 2016). Hal ini disebabkan oleh beberapa hal yang diantaranya siswa kurang berminat dalam pembelajaran matematika, proses pembejaran yang masih mengandalkan guru sebagai pemberi seluruh informasi materi matematika, sarana pembelajaran yang masih kuraang serta aspek psikologis siswa dalam pembelajaran.

Hasil penlitian Aunurrofiq \& Junaedi (2017), menyatakan bahwa kecemasan matematik dan kemampuan pemecahan masalah memiliki hubungan yang tidak linear. Kemampuan pemecahan masalah matematis siswa juga dipengaruhi negatif oleh kecemasan matematik sebesar 57,1\% (Hidayat \& Ayudia, 2019). Penelitian Anita (2014) mengatakan bahwa adanya hubungan kecemasan dan pengaruhnya terhadap kemampuan koneksi matematis. Sedangkan Sakarti (2018) membahas tentang hubungan kecemasan dan kemampuan siswa dalam menyelesaikan masalah matematika. Sehingga salah satu faktor dari kemampuan penyelesaian masalah matematika siswa yakni faktor psikologi (kecemasan). Faktor psikologis merupakan faktor yang berperan sangat besar dalam pencapaian hasil belajar meliputi motivasi, sikap, disiplin, dan lainnya (Blatt, Schunn, Votruba-Drzal \& Rottman, 2020; Bessant, 1995). Siswa yang mengalami fakor psikologis cenderung mengalami kesulitan saat belajar (Cirino, Fuchs, Elias, Powell, \& Schumacher, 2015). Kesulitan siswa dalam menghadapi matematika memunculkan perasaan cemas yang menyebabkan siswa menjadi pasif dan ketidakmampuan dalam menyelesaikan masalah yang diberikan (Winarso \& Haqq, 2019).

Berdasarkan hasil observasi di kelas X AKL 1 siswa mengalami kecemasan dengan ratarata kategori sedang. Indikator yang ditampilkan subyek berada pada tingkatan yang berbeda-beda. Menurut Arem dalam (Sutame, Hapsari, \& Jabar, 2012) terdapat lima tahapan seseorang mengalami kecemasan. Tahapan pertama adalah faktor penyebab kecemasan matematika diantaranya pengalaman yang memalukan, pengalaman negatif yang berhubungan dengan 
pembelajaran matematika, tekanan sosial dan harapan, keinginan menjadi sempurna serta metode pembelajaran yang buruk. Tahapan kedua berpikir negatif, tahapan ketiga cemas dan perasaan tidak nyaman, tahapan keempat gejala fisik dan mental serta tahapan terakhir yakni menghindari matematika. Kecemasan ini perlu penanganan jika intensitas nya tidak terlalu kuat dan bernilai negatif, karena menurut para ahli psikologis kecemasan dapat mengganggu kinerja seseorang dalam belajar (Sugiatno, Priyatno \& Riyanti, 2020).

Untuk itu perlu penanganan dalam mengatasi kecemasan matematika. Pada bidang psikologi kepribadian terdapat banyak model terapi atau konseling. Salah satu nya adalah terapi behavioral (Granvold \& Anderson, 1995). Terapi behavioral merupakan sebuah pendekatan yang diarahkan pada tujuan-tujuan untuk memperoleh tingkah laku baru yang lebih baik, menghapuskan tingkah laku lama yang kurang baik, serta memperkuat dan mempertahankan tingkah laku yang diinginkan (Wenzel, Dobson, \& Hays, 2016). Jenis psikoterapi yang cukup berhasil untuk mengatasi takut dan fobia ialah desensitisasi sistematis yang dikembangkan oleh Wolpe dan penyempurnaan dari penerapan pengurangan kecemasan (Wolpe, 1964). Desensitisasi Sistematis merupakan teknik yang paling luas digunakan dalam terapi tingkah laku. Desensitisasi merupakan salah satu teknik untuk mengurangi respon emosional yang menakutkan, mencemaskan atau tidak menyenangkan melalui aktivitas-aktivitas yang bertentangan dengan respon yang menakutkan itu (Azmarina, 2015).

Desensitisasi Sistematis sendiri merupakan salah satu teknik yang paling luas digunakan dalam terapi tingkah laku (Fitriani \& Supradewi, 2019). Desensitisasi sistematis digunakan untuk menghapus tingkah laku yang diperkuat secara negatif, dan menyertakan pemunculan tingkah laku atau respon yang berlawanan dengan tingkah laku yang hendak dihapuskan itu, Desensitisasi diarahkan kepada mengajar klien untuk menampilkan suatu respon yang tidak konsisten dengan kecemasan (Majid, 2020)

Penelitian Angelina (2015) membahas upaya menangani kecemasan siswa dalam menghadapi ujian menggunakan desensitisasi sistematis. Sementara itu, Tresna (2011) membahas tentang efektifitas konseling behavioral dengan teknik desensitisasi sistematis untuk mereduksi kecemasan dalam menghadapi ujian nasional. Salah satu penggunaan konseling behavioral dengan teknik desensitisasi sistematis yang mempunyai pengaruh yang signifikan ini dilakukan oleh Astuti (2018) dengan ditunjukkannya hasil kecemasan kelas kontrol lebih tinggi dibandingkan kelas eksperimen. Beberapa penelitian tersebut, belum adanya penelitian terkait kecemasan penyelesaian masalah matematika, sehingga hal ini menjadi motivasi untuk melakukan penelitian yang diharapkan dapat mengatasi kecemasan penyelesaian masalah matematika yang ditangani menggunakan terapi behavioral dengan teknik desensitisasi sistematis.

Tujuan dalam penelitian ini yakni untuk megetahui hasil dari penerapan terapi behavioral dengan teknik desensitisasi dapat mengatasi kecemasan dalam menyelesaikan masalah matematika. Sehingga mengkaji kecemasan penyelesaian masalah matematika siswa, kemudian penelitian ini juga mengkaji lebih mendalam mengenai upaya penanganan terapi behavioral menggunakan teknik desensitisasi sistematis. Asumsi tersebut dibangun karena kecemasan mempengaruhi tingkah laku siswa dalam mengambil suatu keputusan yang terkait dengan penyelesaian masalah sosial maupun masalah matematika. Terapi behavioral dengan teknik desensitisasi sistematis dianalisis lebih jauh untuk menunjukkan keefektivitasannya dalam menangani kecemasan penyelesaian masalah matematika yang dihadapi siswa. 


\section{Metode}

Penelitian ini merupakan jenis penelitian dengan pendekatan kualitatif dengan Tipe Studi Kasus (Houghton, Murphy, Shaw \& Casey, 2015). Prosedur penelitian ini berdasarkan desain penelitian studi kasus yakni 1) identifikasi kasus, yaitu menandai subyek yang diduga mengalami kecemasan berupa observasi awal sikap; 2) identifikasi masalah, yaitu menganalisis karakteristik kecemasan yang alami subyek berupa penyebaran skala kecemasan; 3) diagnosis, yaitu mengklasifikasikan karakteristik berdasarkan 4 tingkatan kecemasan serta menganalisa faktor penyebab kecemasan berupa wawancara; 4) Prognosis, yaitu menganalisis tindakan yang akan di beri sesuai dengan tingkatan kecemasan berdasarkan faktor penyebabnya serta penyusunan hierarki kecemasan. Penelitian ini dilaksanakan di SMK Islamic Centre Cirebon 2019/2020. 5) Tindakan, yaitu berupa tahapan terapi yang memuat 9 tahap penerapan dalam kelas. 6) Evaluasi, baik tiap pertemuan maupun secara keseluruhan. Subyek penelitian ini adalah siswa kelas X AKL 1 SMK Islamic Centre Cirebon yang berjumlah 25 siswa.

Metode pengumpulan data penelitian yaitu a) Metode Observasi, yaitu pengamatan langsung sikap dan ekspresi siswa sebelum mengalami kecemasan, saat mengalami kecemasan dan setelah menerapkan terapi; b) Metode Wawancara, yaitu untuk mengetahui faktor penyebab kecemasan yang dialami siswa; c) Metode skala kecemasan, yaitu untuk megetahui tingkat kecemasan yang dialami siswa; d) Metode Dokumentasi, yaitu dengan mendokumentasikan alur kegiatan selama penelitian agar penelitian menjadi empirik. Serta keabsahan data dalam penelitian ini menggunakan triangulasi sumber.

Teknik analisis data yang dilakukan yakni adalah data reduction (reduksi data), display (penyajian data) dan conclusion drawing (analisis data) atau verification (penarikan kesimpulan) (Hashimov, 2015). Pada proses reduksi data, terdapat tahapan yang harus dilakukan peneliti yakni : (1) Mengkategorikan data, ialah upaya memilih setiap satuan data ke bagian-bagian yang memiliki kesamaan. (2) Interpretasi data, yakni penjelasan rinci tentang arti sebenarnya dari data penelitian. Maka data yang telah di reduksi akan memberikan gambaran yang lebih detail sehingga memudahkan peneliti untuk melakukan Pengumpulan data. Dalam penelitian ini, peneliti melakukan pemilihan data yang diperoleh dari skala kecemasan siswa sebagai bahan tindak lanjut terapi behavioral, kemudian data diklasifikasikan kedalam 4 kategori yakni kecemasan ringan, sedang berat dan panik. Serta hasil wawancara yang disusun secara sederhana dengan bahasa sesuai dengan ejaan yang digunakan (EYD) kemudian direpresentasikan dalam bentuk catatan. Berikutnya Data disajikan dalam bentuk uraian singkat, bagan dan hubungan antar kategori dan pedoman penilaian yang telah ditentukan. Miles dan huberman menyatakan paling banyak digunakan dalam penelitian kualitatif menggunakan penyajian dalam bentuk naratif. Melalui langkah penyajian data ini maka akan memudahkan memahami apa yang terjadi serta merencanakan kerja selanjutnya berdasarkan apa yang telah dipahami. Dalam penelitian ini, peneliti menyajikan hasil wawancara dalam penerapan terapi behavioral dengan teknik desensitisasi sistematis yang telah direkam pada alat perekam. Selain itu, peneliti menyajikan hasil analisis faktor kecemasan penyelesaian masalah matematika yang diperoleh dari wawancara. Serta penyajian analisis tahapan penerapan terapi behavioral di kelas. Maka analisis data yang akan dianalisis menggunakan alur jaringan mengenai kecemasan penyelesaian masalah matematika yang didalamnya memuat faktor dan penanggulangannya menggunakan terapi behavioral dengan teknik desensitisasi sistematis sehingga dapat dilihat pengaruh penerapan terapi behavioral dengan menggunakan teknik desensitisasi sistematis. 
Skala kecemasan dirancang menggunakan skala guttman dan skala T-MAS. Skala tersebut digunakan untuk mengetahui tingkat kecemasan siswa dalam menyelesaikan masalah matematika. Namun sebelum digunakan sebagai intrumen penelitian, terlebih dahulu divalidasi ahli (expert judgment) melalui tahapan focus group discussion FGD. kriteria yang menjadi tim penilai intrumen penelitian terdiri dari ahli dibidang pendidikan matematika dan psikologi pendidikan yang terdiri dari dosen dan guru sebagai praktisi pembelajaran matematika. Adapun kategori skala kecemasan yang digunakan berdasarkan skala guttman (Bech, 1990; Yáñez-Marquina \& Villardón-Gallego, 2017).

Tabel 1.Kategori skala kecemasan berdasarkan skala Guttman

\begin{tabular}{cc}
\hline Persentase (\%) & Kriteria \\
\hline $0 \%-20 \%$ & Sangat rendah \\
$21 \%-40 \%$ & Rendah \\
$41 \%-60 \%$ & Sedang \\
$61 \%-80 \%$ & Tinggi \\
$81 \%-100 \%$ & Sangat Tinggi \\
\hline
\end{tabular}

Serta kategori kecemasan berdasarkan skala kecemasan penyelesaian masalah matematika yang dikembangkan peneliti berdasarkan ketentuan skala guttman. Adapun kategori skala kecemasan tersebut diinterpretasikan pada tabel 2 berikut.

Tabel 2. Kategori kecemasan berdasarkan Skala T-MAS

\begin{tabular}{cc}
\hline Skor & Kriteriakecemasan \\
\hline$x<15$ & Tidak Cemas \\
$15<x<20$ & Ringan \\
$20 \leq x \leq 25$ & Sedang \\
$26 \leq x \leq 30$ & Berat \\
$x>30$ & Panik \\
\hline
\end{tabular}

\section{Hasil dan Pembahasan}

Tahapan pertama berdasarkan hasil observasi, ditandai beberapa subyek yang diduga mengalami kecemasan penyelesaian matematika, di dukung dengan data sekunder berupa hasil ulangan siswa yang rendah.adapun sikap siswa yang dijadikan identifikasi kecemasan siswa pada tabel 3 .

Tabel 3. Identifikasi Kasus Kecemasan Siswa

\begin{tabular}{cl}
\hline Subyek & \multicolumn{1}{c}{ Sikap siswa } \\
\hline Subyek 1 & $\begin{array}{l}\text { Dalam pembelajaran subyek 1 cenderung acuh, baik saat guru menerangkan } \\
\text { bahkan saat diminta menyelesaikan masalah yang diajukan, bahkan gaduh saat } \\
\text { diminta menyelesaikan nya secara mandiri. Selama pembelajaran subyek 1 dapat } \\
\text { dihitung 2 sampai 3 kali meminta izin keluar kelas dan kembali dengan rentang } \\
\text { waktu yang cukup lama. }\end{array}$ \\
\hline Subyek 2 & $\begin{array}{l}\text { Berpura-pura tidak melihat saat guru meminta salah satu dari mereka membantu } \\
\text { menyelesaikan soal di depan kelas namun sangat memperhatikan serta tanggap } \\
\text { apabila diberikan stimulus. Misalnya diminta menyelesaikan masalah secara } \\
\text { mandiri. subyek 2 sangat aktif bertanya terkait langkah dan jawaban yang ia } \\
\text { kerjakan pada guru dan pada teman. }\end{array}$ \\
\hline
\end{tabular}



Subyek 3 Pasif dan tegang selama pembelajaran, sangat pendiam dalam menyelesaikan masalah tidak bertanya pada guru maupun teman. Namun subyek 3 sangat terpaku pada contoh soal yang diberikan
Subyek 4 Dalam pembelajaran mendominasi membuat kegaduhan dengan berbincang- bincang dengan teman bukan terkait masalah yang diajukan. Saat menyelesaikan masalah, cenderung pasif dan bahkan bertanya terkait rumus yang harus digunakan. Saat diminta mengerjakan secara mandiri, subyek 4 sangat aktif bertanya terkait cara dan hasil yang ia dapat. Selalu mengingatkan guru untuk segera menutup pembelajaran walaupun waktu masih tersisa 10 menit. Selama pembelajaran subyek 4 dan subyek 8 terhitung satu atau dua kali meminta izin keluar kelas dan kembali dengan membawa jajanan di kantongnya.
Subyek 5 Pasif saat dibuka sesi pertanyaan berpura-pura menulis dan terlihat gugup saat diminta mengerjakan soal di depan kelas. Saat diminta menyelesaikan masalah dengan mandirim subyek 5 cenderung bekerja sama dengan teman dan berbincang- bincang tidak terkait pembelajaran.

Subyek 6 Subyek 6 saat diminta menyelesaikan masalah di depan kelas tangan nya berkeringat dan sangat dingin. Sebelum diminta menyelesaikan, subyek 6 ini banyak bertanya pada guru terkait hasil yang ia dapatkan dan langkah yang dikerjakan. Tegang dan gugup saat mengerjakan di depan kelas, dan mengatakan pada guru bahwa ia gugup dan dingin pada telapak tangan.

Subyek 7 Pasif dan pura-pura tidak melihat saat dibuka sesi pertanyaan dan aktif berbincangbincang tidak terkait pembelajaran, saat diminta menyelesaikan masalah subyek 7 melakukannya dengan bekerja sama dengan teman, dan sunyi saat diminta salah satu dari siswa membantu menyelesaikan soal di depan kelas.

Subyek 8 Sangat aktif berbincang-bincang dengan subyek 4 dan mendominasi kegaduhan. Saat diminta menyelesaikan masalah, bertanya terus menerus pada guru dan saat selesai mengerjakan di depan kelas meminta untuk teman yang sudah selesai didahulukan. Selama pembelajaran subyek 4 dan subyek 8 terhitung satu atau dua kali meminta izin keluar kelas dan kembali dengan membawa jajanan di kantongnya.

Subyek 9 Pasif dan banyak melamun selama pembelajaran. Namun saat diminta menyelesaikan soal di depan kelas menjadi panik dan bertanya terus menerus ke meja guru terkait langkah dan hasil yang ia dapat. Saat selesai mengerjakan di depan kelas, subyek 9 sibuk melakukan kegiatan lain.

Subyek 10 Terlihat tegang selama pembelajaran dan sangat aktif bertanya pada teman padahal masalah yang diberikan sama persis dengan contoh yang dijelaskan sebelumnya. Saat dibuka sesi bertanya, subyek 10 sibuk mencoret-coret buku.

Subyek 11 Pasif selama pembelajaran namun sangat aktif dengan tidak memperhatikan guru saat menjelaskan dan berbincang-bincang tidak terkait dengan masalah yang diajukan. Pada saat dibuka sesi bertanya, subyek 11 berpura-pura tidak melihat dan sibuk mencoret-coret buku.

Subyek 12 Sangat pasif dalam pembelajaran, saat menyelesaikan masalah secara mandiri pun tidak bertanya pada guru. Pembawaan diri yang sangat tenang dengan ekspresi yang selalu datar.

Subyek 13 Pasif selama pembelajaran terus menerus bertanya pada teman yang sudah menyelesaikan soal di depan.

Subyek 14 Sangat ketergantungan pada teman sebangkunya yang merupakan murid aktif di kelas sehingga dalam pengerjaan masalah, subyek 14 banyak bertanya pada teman 
sebangkunya dan sangat panik saat diminta menyelesaikan masalah berbeda soal dengan temannya.

Subyek 15 Sangat aktif dalam berbincang-bincang tidak terkait dengan pembelajaran. Saling bekerja sama saat diminta menyelesaikan masalah secara mandiri. Namun pasif saat dibuka sesi bertanya cenderung menyibukkan diri dengan melakukan kegiatan lain.

Subyek 16 Sangat aktif dalam pembelajaran, merespons stimulus yang diberikan guru dan membantu guru dalam menyelesaikan contoh soal di depan.

Subyek 17 Sangat aktif bertanya saat dibuka sesi bertanya dan sangat kritis pada keterkaitan antar materi

Subyek 18 Pasif dalam pembelajaran dan sangat aktif bertanya saat diminta menyelesaikan soal secara mandiri. Namun setelah mengerjakan menjadi banyak mengacuhkan lingkungan sekitar dengan sibuk bermain ponsel. Saat yang lainnya menulis, ia malah memfotonya dengan alasan tidak membawa buku matematika. Namun pertemuan selanjutnya ia melakukannya lagi.

Subyek 19 Sangat pasif dalam pembelajaran serta berpaku pada contoh soal saat diminta mengerjakan soal secara mandiri. Namun saat dibuka sesi bertanya cenderung tegang dan sunyi dengan menyibukkan pura-pura tidak melihat.

Subyek 20 Pasif dalam pembelajaran dan aktif tidak terkait dengan pembelajaran. Terlihat panik dan terus menerus bertanya terkait langkah penyelesaian pada guru.

Subyek 21 Mandiri dalam mengerjakan namun terus menerus bertanya. Namun saat dibuka sesi bertanya sama seperti yang lainnya pura-pura tidak melihat dan sibuk melakukan kegiatan lainnya.

Subyek 22 Tegang dan sedikit terbata-bata saat bertanyakan rumus mana yang harus digunakan. Namun selama pembelajaran cenderung pasif, dan menjadi aktif dengan bekerja sama menyelesaikan masalah walaupun sudah diinstruksikan mengerjakan mandiri.

Subyek 23 Subyek 23 dan subyek 25 terhitung dua kali terlambat memasuki kelas serta selama pembelajaran satu sampai dua kali meminta izin keluar kelas dan kembali dalam durasi waktu yang lama. Selama pembelajaran cenderung cuek namun saat ditanya ia mampu menjawab dengan benar, dan saat diminta menyelesaikan masalah dengan mandiri dan cepat ia mampu melakukan sesuai instruksi namun setelahnya kembali menyibukkan diri dengan melamun.

Subyek 24 Sangat aktif dalam menanggapi stimulus yang diberikan oleh guru, sedikit terbatabata ketika diminta guru menyimpulkan akhir pembelajaran. Dapat menyelesaikan masalah secara mandiri namun setelahnya menyibukkan diri dengan bermain ponsel.

Subyek 25 Subyek 25 terhitung dua kali terlambat masuk kelas dan sering meminta izin untuk ke kamar mandi namun kembali dengan rentang waktu yang lama. Saat diminta menjelaskan langkah yang ia dapatkan, ia tidak bisa menjelaskannya dan mengucapkan dengan nada suara yang bergetar serta raut muka yang tegang. Saat menyelesaikan masalah secara mandiri, ia justru dijelaskan ulang contoh yang baru saja dibahas baru kemudian ia bisa mengerjakannya. Hal tersebut pun berkali-kali ditanyakan pada guru terkait langkah dan hasil yang didapat.

Berdasarkan kondisi awal tersebut, peneliti menandai beberapa subyek yang diduga mengalami kecemasan penyelesaian matematika, didukung dengan data sekunder berupa hasil ulangan siswa yang rendah. Di antaranya Subyek 1, Subyek 2, Subyek 4, Subyek 8, Subyek 9, 
Subyek 10, Subyek 11, Subyek 15, Subyek 22, Subyek 23, dan Subyek 25. Gejala yang ditunjukkan seperti siswa meminta ijin ke kamar mandi dan kembali dengan rentang waktu yang cukup lama, ketika guru memberikan stimulus hanya beberapa yang menanggapi sisanya siswa menundukkan wajahnya dan memegang pulpen serta mencoret-coret buku, saat guru meminta untuk salah satu dari mereka membantu menyelesaikan masalah yang diajukan pun terlihat sikap yang sama menundukkan wajah dan berpura-pura tidak mendengar.

Kecemasan semakin terlihat saat guru meminta tiap siswa menyelesaikan masalah yang diajukan didepan kelas dan menjelaskan langkah pengerjaan pada teman-teman. Sikap yang mereka tunjukkan seperti : tangan yang berkeringat dan sangat dingin, gugup serta terbata-bata saat menjelaskan bahkan ada yang tidak dapat menjelaskan sama sekali, sikap panik sangat tampak sebagian siswa dengan berulangkali menyanyakan perihal rumus, langkah pengerjaan bahkan jawaban yang mereka dapat. Selanjutnya, saat diajukan masalah dengan masalah yang berbeda satu dengan yang lainnya muncul sikap gelisah dan menanyakan terus menerus langkah pengerjaan pada guru juga pada teman. Gejala-gejala yang ditampilkan secara fisik dan gejala secara psikologis diantaranya; 1) Gejala fisik ditandai dengan tangan dan kaki yang berkeringat, meningkatkan kerja detak jantung, tangan terkepal, gemetaran dan mulut kering. 2) gejala psikologis ditandai dengan panik, takut, khawatir, keinginan untuk menghindari situasi dan ketidakmampuan mengatasi persoalan dalam matematika (Passolunghi, Caviola, De Agostini, Perin, \& Mammarella, 2016; Imro'ah, Winarso, \& Baskoro, 2019).

Selanjutnya, menyebar skala kecemasan dalam penyelesaian masalah matematika pada 25 Subyek untuk menunjukkan tingkat kecemasan masing-masing subyek dalam menyelesaikan masalah matematika. Adapun hasil penyebaran skala diinterpretasikan dalam perhitungan psikologi menggunakan skala T-MAS dan skala Guttman pada gambar 1 berikut.

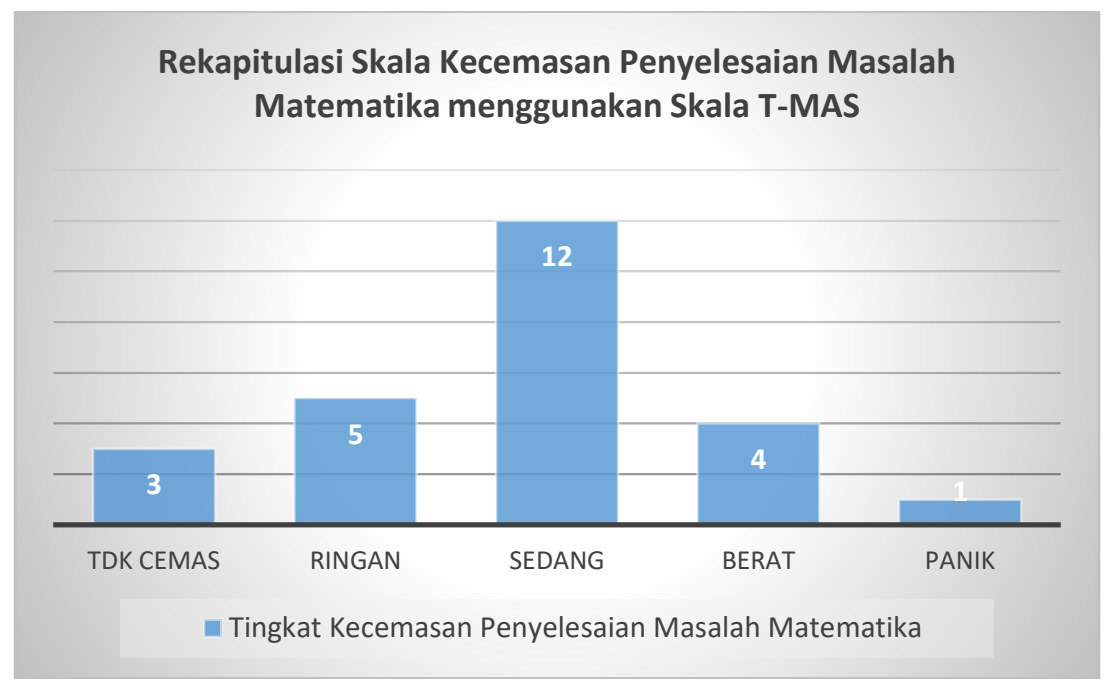

Gambar 1. Tingkat kecemasan siswa sebelum terapi

Berdasarkan gambar 1, terdapat 25 Subyek yang 3 siswa yang tidak mengalami kecemasan, 5 siswa mengalami kecemasan tingkat ringan, 12 siswa mengalami kecemasan tingkat sedang, 4 siswa mengalami kecemasan tingkat berat dan 1 siswa mengalami kecemasan tingkat panik. 


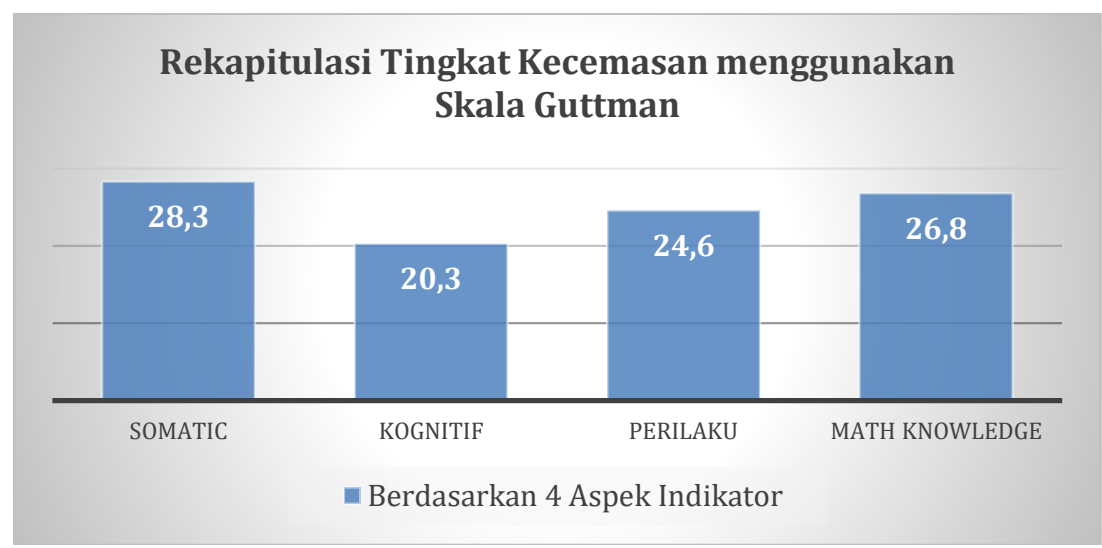

Gambar 2. Tingkat kecemasan menggunakan skala guttman

Berdasatkan gambar 2, analisis skala Guttman dari 50 item pertanyaan berdasarkan 4 indikator, aspek somatic menunjukkan prosentase $28,3 \%$, aspek kognitif menunjukkan prosentase $20,3 \%$, aspek perilaku menunjukkan persentase $24,6 \%$ dan aspek math knowledge $26,8 \%$ dengan sebaran skor rata-rata tiap item $44,88 \%$ jika di interpretasikan termasuk dalam kecemasan dengan kriteria sedang.

Tahap kedua, dilakukan wawancara sebagai upaya mengetahui penyebab kecemasan yang dialami siswa. Berdasarkan hasil wawancara 22 responden rata-rata mengalami kecemasan yang disebabkan oleh teman. Responden mengalami ketergantungan dengan teman, kebingungan saat mengerjakan masalah yang diberikan, tidak sedikit dari mereka diam menunggu temannya selesai mengerjakan lalu bertanya terkait langkah pengerjaan. Ketergantungan dengan teman tidak hanya saat pembelajaran, saat ujian pun responden merasa kesulitan untuk menyelesaikan masalah yang di ajukan. Selain ketergantungan pada teman yang memperkuat ketidakpercayaan diri siswa, karena siswa mengalami kegelisahan saat teman-teman yang lain sudah menyelesaikan masalah yang di ujikan, sedangkan durasi waktu pengerjaan akan berakhir. Hal tersebut berdasarkan penelitian yang relevan bahwa terdapat hubungan pertemanan dengan kecemasan (Rodebaugh, Lim, Shumaker, Levinson, \& Thompson, 2015; Rector, Kocovski \& Ryder, 2006).

Faktor selanjutnya yang banyak mempengaruhi kecemasan siswa yakni faktor pengajar. Faktor pengajar yang menyamaratakan kemampuan setiap siswa menjadi salah satu penyebabnya. Pernyataan ini selaras dengan kondisi kelas saat guru menanyakan perihal paham tidak nya materi yang telah di jelaskan, beberapa menjawab paham sedangkan lainnya diam tidak ada yang bertanya atau mengangkat tangan saat belum memahami penjelasan yang guru sampaikan. Hal ini menyulitkan guru terkait tercapai atau belumnya materi yang disampaikan serta sudah dikuasai atau belum oleh siswa. Hal tersebut sejalan dengan berdasarkan penelitian Peker (2009) dan Sriyana \& Winarso, (2018) bahwa indikasi sikap siswa inilah yang agaknya menjadi tolak ukur guru dalam menyamaratakan setiap siswa.

Setelah di observasi, tidak banyak siswa memiliki masa lalu yang buruk dengan matematika seperti disetrap/hukum karena tidak mengerjakan tugas, guru yang galak dan menunjuk acak untuk menyelesaikan soal didepan kelas, mendapat nilai 0, karena guru tidak memberikan stimulus terlebih dahulu tetapi siswa langsung diminta mengerjakan soal dipapan tulis. Serta guru yang memerintah mengerjakan sesuatu jika ada siswa yang bertanya soal matematika. Hal demikian membuat siswa terkesan menghindari bertanya terkait matematika dan memilih diam, karena guru akan memberi perintah untuk siswa mengerjakan hal seperti 
membersihkan sampah atau mengerjakan soal di depan. Hal tersebut sejalan dengan hasil penelitian bahwa kondisi semacam itu dapat berpengaruh terhadap psikologis siswa terutama motivasi dalam belajar di kelas (Ahmad, Said \& Khan, 2013).

Pembelajaran student center yang diberlakukan oleh pemerintah, sepertinya membuat siswa belum siap untuk mengikutinya. Hal ini juga selaras dengan pembelajaran yang diterapkan di kelas guru dalam mengajar. Belum terbiasanya menggunakan Student center ini, hal yang siswa alami saat gurunya mengajar dan menerapkan pembelajaran diskusi serta presentasi di kelas maka timbul kecemasan yang siswa tunjukkan. Penataan kata dan diksi atau pilihan kata yang telah siswa susun pada praktinya saat mengalami cemas mendadak lupa bahkan terdapat siswa yang menghindar dan mengalihkan pada temannya. Belum terbiasa tampil di depan kelas atau mengerjakan masalah yang diajukan secara mandiri sangat mempengaruhi faktor intelektual siswa. Lupa dalam langkah pengerjaan bahkan tidak memahami maksud dari masalah yang di ajukan hingga bingung menggunakan rumus yang akan digunakan.

Namun pada penelitian ini, menemukan siswa yang memiliki intelektual di atas rata-rata, akan tetapi siswa megalami kecemasan dengan tingkat berat yakni responden 23. Setelah melakukan wawancara ternyata siswa tersebut melakukan hal seperti jarang masuk ke kelas dan sering izin keluar kelas. Hal tersebut, karena siswa tersebut masuk ke jurusan yang tidak di inginkannya, namun karena kuota jurusan penuh maka siswa berpikir untuk masuk sekolah itu terlebih dahulu baru kemudian bisa pindah jurusan. Jarang masuk kelas tidak hanya dilakukan saat pelajaran matematika saja, demikian pula pada mata pelajaran lain.

Dengan demikian faktor lingkungan mempengaruhi seseorang hingga menimbulkan kecemasan. Saat seseorang berada di lingkungan yang sesuai dengan keinginannya maka suasana akan membangkitkan seseorang nyaman dalam belajar, hal ini selaras dengan Muñoz-Laboy, Ripkin, Garcia, \& Severson (2015) terkait dengan konsep keluarga yang mempengaruhi pula dalam kecemasan, namun yang di alami responden 23 ini faktor lingkungan sekolah yang membuatnya tidak nyaman.

Dengan demikian, hasil wawancara kecemasan siswa dalam menyelesaikan masalah matematika disebabkan karena 1) tuntunan orang tua atau guru yang menginginkan hasil yang sempurna serta faktor lingkungan yang bising dan ketergantungan pada teman, 2) pengalaman buruk di masalalu dan ketidakpercayaan diri 3) ketidakmampuan untuk menyelesaikan masalahnya secara mandiri.

Hal tersebut diperkuat dengan faktor kecemasan yang dipaparkan (Sugiatno, Priyatno \& Riyanti, 2020) bahwa dalam studi lapangannya terdapat 3 faktor penyebab siswa mengalami kecemasan matematika yakni faktor kepribadian, faktor intelektual dan faktor lingkungan. Dengan demikian kecemasan pada matematika tidak hanya disebabkan oleh faktor tunggal, tetapi terdapat faktor lain yang juga mempengaruhinya.

Tahap keempat yakni tahap terapi. Terapi behavioral yang diterapkan dikelas ini memiliki 9 tahapan.

1) Pengkondisian. Pada tahapan pengkondisian ini jadwal terapi yang dilakukan pada jam pelajaran kosong atau di luar jam pelajaran dengan 3 pertemuan. Pada masing-masing pertemuan terdapat 3 sesi. Pengkondisian sesi tiap subyek di pertemuan pertama menggunakan skala kecemasan. Subyek yang mengalami kecemasan dengan tingkatan berat 
dan panic berada pada sesi pertama. Sedangkan subyek yang berada pada tingkatan sedang melaksanakan terapi pada sesi kedua dan sesi ketiga dilaksanakan oleh subyek dengan tingkatan ringan.

2) Rasionalisasi. Rasionalisasi dilakukan dengan memaparkan hasil penyebaran skala dan wawancara tentang gejala-gejala yang di alami siswa serta menyebutan kelompok pada sesi terapi. Pada tahapan ini diberikan edukasi bagaimana siswa mengenali gejala-gejala kecemasan yang di alami dan tahap penggunaan teknik desensitisasi sistematis sehingga siswa dapat menggunakan terapi ini secara mandiri.

3) Latihan relaksasi. Berpedoman instruksi relaksasi yang telah disusun sebelumnya. Konselor memberikan contoh relaksasi dan konselor menugaskan meminta siswa melakukan relaksasi sendiri dirumah berpedoman dengan instruksi relaksasi yang di contohkan konselor, serta membuat catatan kecil atau mengingat perubahan yang terjadi setelah melakukan relaksasi.

4) Menyiapkan hierarki kecemasan yang telah di susun dalam bentuk paragraf yang mudah dibayangkan. Pada tahapan ini nantinya akan digunakan untuk memunculkan stimulus kecemasan pada tahap desensitisasi sistematis.

5) Mendiskusikan hal yang membuat konseli nyaman. Pada tahapan ini, konselor menanyakan hal yang membuat konseli nyaman. Kondisi atau hal yang membuat konseli nyaman ini akan di munculkan setelah konseli merespon melalui perubahan ekspresi dan sikap. Tahapan ini merupakan tahap netralisir sebelum konseli mengimajinasikan pada hierarki kecemasan berikutnya.

6) Relaksasi. Sebelum tahap desensitisasi systematis konselor melakukan tahap relaksasi. Tujuan diberikannya relaksasi adalah agar proses inti atau proses desensitisasi sistematis konseli sudah memposisikan dirinya senyaman mungkin.

7) Desensitisasi sistematis. Tahapan inti dalam penelitian ini adalah dengan konseli mengimajinasikan hierarki kecemasan rendah, sedang dan tinggi secara sistematis serta diselingi dengan kondisi yang membuat konseli nyaman. Pertama, Konseli diminta membayangkan matematika itu sangat sulit dan dirinya tidak mampu menyelesaikan matematika. Sekeras apapun mencoba untuk memahami masalah matematika tetap saja tidak mampu memecahkannya dan tidak percaya diri bahwa ia mampu membuat matematika menjadi pelajaran yang disukai juga menyenangkan. Kedua, Konseli diminta membayangkan ketika materi yang telah di sampaikan sebelumnya karena ia merasa cemas dan ketidakpercayaan diri sehingga ia tidak mengetahui maksud dan tujuan dari masalah tersebut bahkan sulit menentukan menggunakan rumus yang mana berlanjut hingga lupa langkah penyelesaian. Ketiga, konseli dimana membayangkan jika diberi masalah matematika oleh guru dan konseli sama sekali tidak di perbolehkan bertanya. Jika guru yang member masalah matematika dikenal sebaai guru yang galak jika salah satu dari konseli ada yang mencontek maka tidak mendapatkan nilai. Serta guru akan terus member masalah matematika sampai nilai konseli mencapai criteria ketuntasan minimum, kemudian konseli diminta membayangkan suasana kelas yang awalnya tenang berubah menjadi gaduh karena hampir semua siswa sudah menyelesaikannya, hanya tersisa konseli di dalam kelas dan karena waktu sudah akan habis konseli sangat terburu-buru mengerjakannya. Saat itu, tiba-tiba konseli lupa langkah pengerjaannya. Konseli pasrah dan menyerahkan lembar masalah matematika seadanya, sama seperti yang di perkirakan konseli harus mengulang untuk menyelesaikan masalah matematka. Hanya konseli sendiri. Semua teman-teman mampu menyelesaikannya. Selanjutnya, setelah konseli menampilkan ekspresi kecemasan yang dialaminya konselor melanjutkan dengan mengimajinasikan hal-hal yang membuat konseli nyaman.

8) Mengamati dan mencatat perubahan sikap dan ekspresi konselor. Pertemuan pertama ini banyak ditemukan sikap panic bahkan saat diinstruksikan relaksasi terdapat konseli yang salah 
dalam melakukan gerakan yang seharusnya memposisikan tangan di atas paham enjadi konseli menempatkannya dibelakang leher. Pertemuan kedua, Ekspresi wajah yang ditampilkan pada terapi ini tidak sepanik seperti terapi pertama, namun masih terjadi perubahan mimic muka yang berkerut dahi dan mengeritkan alis, garis bibir yang menyungging dan kaki yang gemetar. Pertemuan ketiga, Ekspresi yang ditampilkan cukup mengalami perubahan, dahi yang sudah tidak lagi berkerut dan alis yang sudah tidak lagi mengeritkan. Serta tangan yang pada pertemuan awal dingin dan berkeringat menjadi biasa saja meskipun gemetar pada kaki masih di lakukan konseli.

9) Evaluasi. Pada pertemuan pertama konselor memfokuskan pengulangan hierarki kecemasan pada semua tingkatan. Pada terapi kedua ini konselor memberikan evaluasi dengan memperbanyak instruksi pada hierarki sedang dan puncak, hal tersebut dilakukan agar konseli terbiasa jika dimunculkan kecemasan tersebut. Pada terapi terakhir ini konselor memberikan evaluasi dengan memperbanyak instruksi pada hierarki puncak, yakni instruksi dengan factor penyebabnya lingkungan dan sosial.

Tahap akhir yakni evaluasi. konselor paparkan perubahan tingkatan kecemasan yang dialami siswa serta mengedukasi untuk lebih percaya dengan kemampuan yang dimiliki dan mengingatkan kembali tahapan terapi ini dengan tujuan konseli dapat melakukan tiap tahapan terapi tanpa di dampingi konselor jika dirinya merasakan kecemasan. Berikut ini akan diinterpretasikan instruksi relaksasi dan gambar evaluasi skala kecemasan siswa sebelum dan setelah terapi serta tabel perubahan sikap siswa dan pengaruhnya terapi behavioral ini dalam mengatasi kecemasan penyelesaian masalah matematika.

1. Letakkan kedua tangan anda di atas paha, pejamkan mata dan jangan membukanya sebelum saya minta. Pejamkan mata anda secara perlahan, Buatlah badan,pikiran dan perasaan anda senyaman mungkin, serileks mungkin, setenang mungkin, kemudian tarik nafas, tahan, hembuskan perlahan lewat mulut. Bayangkan hal-hal yang membuat anda nyaman, rileks, mungkin semilir angin dipegunungan, hijau, sejuk, atau suasana pantai yang indah, buat hal itu senyata mungkin, hanya anda tanpa ketakutan anda pada matematika, hanya anda dengan kenyamanan anda. Sekali lagi tarik nafas, tahan, hembuskan perlahan lewat mulut. Sekarang buka mata anda.

2. Selanjutnya relaksasi tangan, Luruskan kedua tangan kedepan, 1..2..3.. lepaskan. Rentangkan tangan kesamping, tekukkan jari kebawah 1..2..3.. lepaskan. Angkat tangan keatas rasakan tarikan dari tangan tersbut 1..2..3.. lepaskan.

3. Sekarang kita akan relaksasi pinggang dan leher serta kepala, bungkukkan badan anda ke depan 1..2..3.. lepaskan, kemudian lepangkan badan anda ke belakang 1..2..3.. lepaskan, untuk relaksasi leher dan kepala, tarik nafas, hembuskan perlahan, sekarang miringkan kepala ke kanan 1..2..3.. lepaskan, miringkan kepala ke kiri 1..2..3.. lepaskan, patahkan leher anda ke kanan 1..2..3.. lepaskan, selanjutnya patahkan leher anda ke kiri 1..2..3.. lepaskan

4. Selanjutnya relaksasi otot muka dan mulut, buka mulut anda selebar-lebarnya, selebar mungkin, tahan 1..2..3.. tutup. Tarik nafas, tahan, hembuskan perlahan. Buat badan anda serileks mungkin, letakkan tangan di atas paha, anda sekarang merasakan sangat nyaman, tenang dan gembira, pada hitungan ke 3 buka mata anda 1..2..3.. buka. 
5. Selanjutnya akan kita lakukan relaksasi otot saraf, untuk bisa lebih mengontrol emosi otot dan pita suara, anda bisa bernyanyi dari nada tertinggi hingga terendah. Aaaaa, do, re, mi, fa,sol,la,si,do...

6. Selanjutnya kita akan relaksasi otot mata dan dahi. Pejamkan mata kanan kemudian kiri. Buka. Sekali lagi pejamkan mata yang kanan.. kemudian yang kiri.. buka. Kerutkan dahi sekerut mungkin, lepaskan. Sekali lagi kerutkan dahi sekerut mungkin kemudian lepaskan.

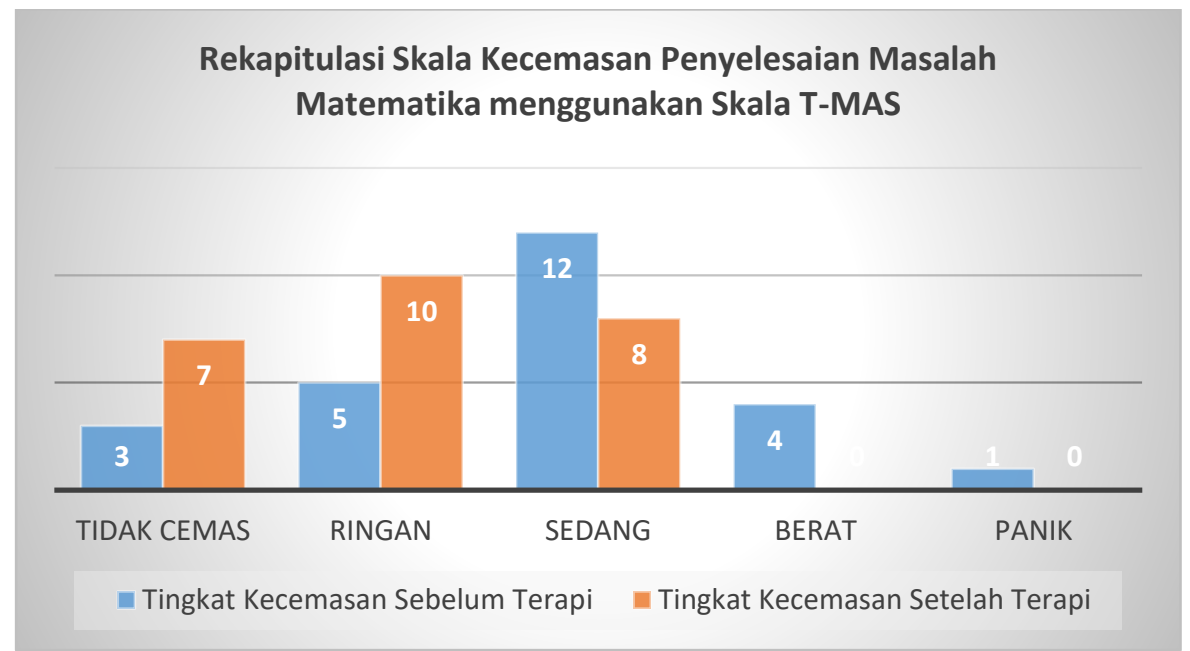

Gambar 3. Skala kecemasan siswa sebelum dan sesudah terapi berdasarkan skala T-MAS

Berdasarkan gambar 3, terdapat 25 Subyek, bertambah 4 siswa yang tidak mengalami kecemasan sehingga siswa yang tidak mengalami kecemasan berjumlah 7, bertambah 5 siswa mengalami kecemasan tingkat ringan sehingga kini jumlahnya 10 siswa, sedangkan terjadi penurunan pada kecemasan tingkat sedang yang semula 12 siswa menjadi 8 siswa dan 0 siswa pada tingkat berat dan panik.

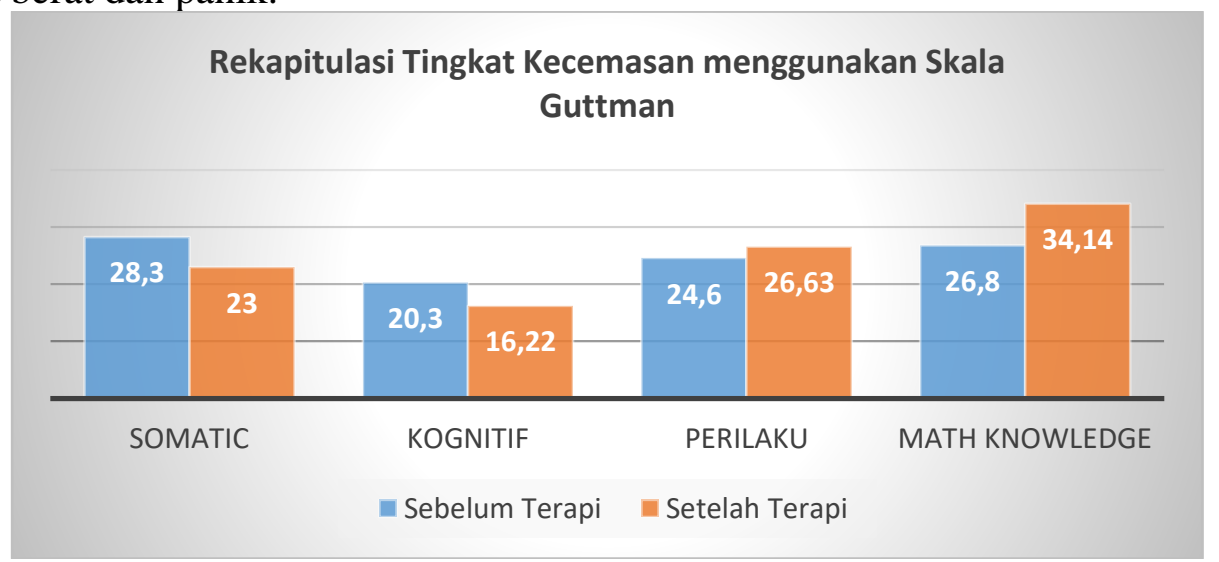

Gambar 4. Skala kecemasan siswa berdasarkan skala Guttman

Berdasarkan gambar 4, analisis skala Guttman dari 50 item pertanyaan berdasarkan 4 indikator, aspek somatic yang semula menunjukkan prosentase $28,3 \%$ menjadi $23 \%$, semula aspek kognitif menunjukkan prosentase $20,3 \%$ menjadi $16,22 \%$, semula aspek perilaku menunjukkan prosentase 24,6\% meningkat menjadi 26,63\% dan aspek math knowledge 26,8\% meningkat menjadi $34,14 \%$ dengan sebaran skor rata-rata tiap item 33,04\% jika di interpretasikan termasuk dalam kecemasan dengan kriteria sedang. 
Tabel. 1 Perubahan Sikap Siswa Sebelum dan Sesudah Terapi

\begin{tabular}{|c|c|c|c|c|c|c|c|}
\hline \multirow{2}{*}{ No. } & \multirow{2}{*}{ Gejala yang tampak } & \multicolumn{3}{|c|}{ Sebelum Terapi } & \multicolumn{3}{|c|}{ Sesudah Terapi } \\
\hline & & $\mathbf{S}$ & KK & TP & $\mathbf{S}$ & KK & TP \\
\hline 1 & $\begin{array}{l}\text { Dahi yang berkerut dan alis } \\
\text { yang menyerit }\end{array}$ & $\checkmark$ & & & & & $\checkmark$ \\
\hline 2 & Gemetar pada Kaki & $\checkmark$ & & & & $\checkmark$ & \\
\hline 3 & $\begin{array}{l}\text { Tangan yang dingin dan } \\
\text { berkeringat }\end{array}$ & $\checkmark$ & & & & & $\checkmark$ \\
\hline 4 & Posisi duduk yang gelisah & $\checkmark$ & & & & & $\checkmark$ \\
\hline 5 & Bertanya pada teman & $\checkmark$ & & & & $\checkmark$ & \\
\hline 6 & $\begin{array}{lrr}\text { Gugup saat mengerjakan } \\
\text { masalah dan bingung saat } \\
\text { menyelesaikan } \\
\text { pengerjaan }\end{array}$ & $\checkmark$ & & & & & $\checkmark$ \\
\hline
\end{tabular}

Keterangan :

$S$ : Sering dilakukan

KK : Kadang-kadang dilakukan

TP : Tidak Pernah dilakukan

Sedangkan untuk melihat tingkat keberhasilan dan kegagalan penerapan terapi behavioral dengan teknik desensitisasi sistematis berpedoman pada standar uji perilaku (Garber, 2015). yang apabila dipersentasekan pada tabel 5.

Tabel. 5 Standar Uji Perilaku

\begin{tabular}{cl}
\hline Persentase & \multicolumn{1}{c}{ Kategori } \\
\hline $75 \%<x<100 \%$ & Berhasil \\
$60 \%<x<75 \%$ & Cukup Berhasil \\
$x<60 \%$ & Kurang Berhasil \\
\hline
\end{tabular}

Dari Tabel. 1 dapat diamati perubahan sikap seperti dahi berkerut dan alis yang menyerit, posisi duduk yang gelisah dan tangan yang dingin dan berkeringat menjadi tidak pernah dilakukan, sedangkan gemetar pada kaki dan bertanya pada teman menjadi kadang-kadang dilakukan, maka diinterpretasikan dalam persentase sebagai berikut :

Gejala yang tidak pernah dilakukan $=\frac{4}{6} \times 100 \%=66 \%$

Gejala yang kadang-kadang dilakukan $=\frac{2}{6} \times 100 \%=34 \%$

Gejala yang sering dilakukan $=\frac{0}{6} \times 100 \%=0 \%$

Berdasarkan persentase gejala-gejala yang tampak pada responden diatas maka penerapan terapi behavioral dengan teknik desensitisasi sistematis dalam mengatasi kecemasan penyelesaian masalah matematika dikatakan cukup berhasil dengan persentase $66 \%$ dengan berpedoman pada standar uji perilaku dimana $60 \%<x<75 \%$ dikategorikan cukup berhasil. Hal tersebut sejalan dengan beberapa hasil penelitian bahwa siswa mengalami penurunan signifikan secara statistik dan klinis dalam kecemasan melalui penerapan terapi behavioral dengan teknik desensitisasi (Passolunghi, De Vita \& Pellizzoni, 2020; Zettle, 2003). 


\section{Kesimpulan}

Kesimpulan dalam penelitian ini, bahwa penerapan terapi behavioral dengan teknik desensitisasi untuk mengatasi kecemasan dalam menyelesaikan masalah matematika. Melalui 9 tahapan dalam terapi behavioral mulai dari; pengkondisian, rasionalisasi, pemberian contoh relaksasi oleh konselor, konselor menyiapkan hierarki kecemasan yang telah disusun dalam bentuk paragraf yang mudah dibayangkan, tahap memunculkan stimulus kecemasan diselingi hal-hal menyenangkan, mengamati dan mencatat perubahan sikap dan ekspresi konseli, dan melakukan evaluasi sebagai tindakan akhir terapi, baik setiap pertemuan maupun evaluasi secara keseluruhan.

Dengan demikian sekolah perlu mengadakan pemrograman mengenai kegiatan bimbingan konseling yang konsisten dan berkesinambungan. Hal ini agar peran dan kewajiban guru BK dan guru mata pelajaran dalam tugasnya dapat berkoordinasi untuk mengatasi permasalahan yang siswa alami serta dapat menggunakan terapi behavioral dengan teknik desensitisasi sistematis untuk mengatasi kecemasan siswa dalam pembelajaran di sekolah

\section{Referensi}

Ahmad, I., Said, H., \& Khan, F. (2013). Effect of Corporal Punishment on Students' Motivation and Classroom Learning. Review of European Studies, 5(4), 130-134. https://doi.org/10.5539/res.v5n4p130

Andersson, A., Valero, P., \& Meaney, T. (2015). "I am [not always] a maths hater": Shifting students' identity narratives in context. Educational Studies in Mathematics, 90(2), 143161. https://doi.org/10.1007/s10649-015-9617-z

Angelina, Y. . (2015). Upaya Mengurangi Kecemasan Menghadapi Ujian Melalui Teknik Konseling Sistematic Desensitization pada Siswa Kelas X di SMA Negeri 1 Bahorok Tahun ajaran 2014-2015 (Doctoral dissertation,). Retrieved from http://digilib.unimed.ac.id/24636/

Anita, I. W. (2014). Pengaruh Kecemasan Matematika (Mathematic Anxiety) terhadap Kemampuan Koneksi matematika Siswa SMP. Infinity Journal, 3(1), 125. https://doi.org/10.22460/infinity.v3i1.43

Astuti. (2018). Efektifitas Konseling Behavioral dengan Teknik Desensitisasi Sistematis Untuk Mengurangi Kecemasan Berkomunikasi didepan Umum pada peserta didik kelas XII SMAN 8 Bandar Lampung. Universitas Islam Negeri Raden Intan Lampung. Retrieved from http://repository.radenintan.ac.id/358/

Aunurrofiq, M., \& Junaedi, I. (2017). Kecemasan Matematik Siswa dalam Menyelesaikan SoalSoal Pemecahan Masalah. Unnes Journal of Mathematics Education Research, 6(2), $157-$ 166. Retrieved from https://journal.unnes.ac.id/sju/index.php/ujmer/article/view/20473

Azmarina, R. (2015). Desentisasi Sistematik dengan Dzikir Tasbih untuk Menurunkan Simtom Kecemasan pada Gangguan Fobia Spesifik. Humanitas: Jurnal Psikologi Indonesia, 12(2), 90-104. https://doi.org/10.26555/humanitas.v12i2.3836

Bech, P. (1990). Psychometric Developments of the Hamilton Scales: The Spectrum of Depression, Dysthymia, and Anxiety. In The Hamilton Scales (pp. 72-79). https://doi.org/10.1007/978-3-642-75373-2_9 
Bessant, K. C. (1995). Factors associated with types of mathematics anxiety in college students. Journal for research in mathematics education,26(4), 327-345. https://doi.org/10.2307/749478

Blatt, L., Schunn, C. D., Votruba-Drzal, E., \& Rottman, B. M. (2020). Variation in which key motivational and academic resources relate to academic performance disparities across introductory college courses. International Journal of STEM Education,7(1), 1-25. https://doi.org/10.1186/s40594-020-00253-0

Cirino, P. T., Fuchs, L. S., Elias, J. T., Powell, S. R., \& Schumacher, R. F. (2015). Cognitive and Mathematical Profiles for Different Forms of Learning Difficulties. Journal of Learning Disabilities, 48(2), 156-175. https://doi.org/10.1177/0022219413494239

Fauziah, G., \& Lestari, A. W. (2018). Pembudayaan Gerakan Literasi Informasi Siswa Tingkat $\begin{array}{lllll}\text { Sekolah Dasar Di Tanggerang Selatan. Edulib, } & \text { 8(2), }\end{array}$ https://doi.org/10.17509/edulib.v8i2.13490

Fitriani, A., \& Supradewi, R. (2019). Desensitisasi Sistematis dengan Relaksasi Zikir untuk Mengurangi Gejala Kecemasan pada Kasus Gangguan Fobia. PHILANTHROPY: Journal of Psychology, 3(2), 75-88. https://doi.org/10.26623/philanthropy.v3i2.1689

Garber, B. D. (2015). Cognitive-Behavioral Methods in High-Conflict Divorce: Systematic Desensitization Adapted to Parent-Child Reunification Interventions. Family Court Review, 53(1), 96-112. https://doi.org/10.1111/fcre.12133

Granvold, D. K., \& Anderson, S. K. (1995). Cognitive and Behavioral Treatment: Methods and Applications. Journal of Cognitive Psychotherapy, 9(4), 295-297. https://doi.org/10.1891/0889-8391.9.4.295

Hashimov, E. (2015). Qualitative Data Analysis: A Methods Sourcebook and The Coding Manual for Qualitative Researchers. Technical Communication Quarterly, 24(1), 109-112. https://doi.org/10.1080/10572252.2015.975966

Hidayat, W., \& Ayudia, D. B. (2019). Kecemasan matematik dan kemampuan pemecahan masalah matematis siswa SMA. Kalamatika: Jurnal Pendidikan Matematika, 4(2), 205-214. https://doi.org/10.22236/kalamatika.vol4no2.2019pp205-214

Houghton, C., Murphy, K., Shaw, D., \& Casey, D. (2015). Qualitative case study data analysis: an example from practice. Nurse Researcher, 22(5), 8-12. https://doi.org/10.7748/nr.22.5.8.e1307

Imro'ah, S., Winarso, W., \& Baskoro, E. P. (2019). Analisis Gender terhadap Kecemasan Matematika dan Self Efficacy Siswa. KALAMATIKA Jurnal Pendidikan Matematika, 4(1), 23-36. https://doi.org/10.22236/KALAMATIKA.vol4no1.2019pp23-36

Majid, A. N. (2020). Teknik desensitisasi sistematis melalui sholawat wahidiyah untuk mengatasi fobia sirene ambulan pada seorang remaja di Desa Kendal Kecamatan Kendal Kabupaten Ngawi (Doctoral dissertation, UIN Sunan Ampel Surabaya). Retrieved from http://digilib.uinsby.ac.id/41839/

McComas, W. F. (2014). Trends in International Mathematics and Science Study (TIMSS). In The Language of Science Education (pp. 108-108). https://doi.org/10.1007/978-94-6209-4970_97

Muñoz-Laboy, M., Ripkin, A., Garcia, J., \& Severson, N. (2015). Family and Work Influences on 
Stress, Anxiety and Depression Among Bisexual Latino Men in the New York City Metropolitan Area. Journal of Immigrant and Minority Health, 17(6), 1615-1626. https://doi.org/10.1007/s10903-015-0220-2

Noordyana, M. A. (2016). Meningkatkan Kemampuan Berpikir Kritis Matematis Siswa melalui Pendekatan Metacognitive Instruction. Mosharafa: Jurnal Pendidikan Matematika, 5(2), 120-127. https://doi.org/10.31980/mosharafa.v5i2.267

Novaliyosi. (2018). The Development of Instruments to Measure Student Mathematical Logical Thinking Ability in Kapita Selekta. SHS Web of Conferences, 42, 00054. https://doi.org/10.1051/shsconf/20184200054

Passolunghi, M. C., Caviola, S., De Agostini, R., Perin, C., \& Mammarella, I. C. (2016). Mathematics Anxiety, Working Memory, and Mathematics Performance in SecondarySchool Children. Frontiers in Psychology, 7(42), 1-8. https://doi.org/10.3389/fpsyg.2016.00042

Passolunghi, M. C., De Vita, C., \& Pellizzoni, S. (2020). Math anxiety and math achievement: The effects of emotional and math strategy training. Developmental science, 23(6), 1-12. https://doi.org/10.1111/desc.12964

Peker, M. (2009). Pre-Service Teachers' Teaching Anxiety about Mathematics and Their Learning Styles. EURASIA Journal of Mathematics, Science and Technology Education, 5(4), 335345. https://doi.org/10.12973/ejmste/75284

Rector, N. A., Kocovski, N. L., \& Ryder, A. G. (2006). Social anxiety and the fear of causing discomfort to others: conceptualization and treatment. Journal of social and clinical psychology, 25(8), 906-918. https://doi.org/10.1521/jscp.2006.25.8.906

Rodebaugh, T. L., Lim, M. H., Shumaker, E. A., Levinson, C. A., \& Thompson, T. (2015). Social anxiety and friendship quality over time. Cognitive Behaviour Therapy, 44(6), 502-511. https://doi.org/10.1080/16506073.2015.1062043

Sakarti, H. (2018). Hubungan Kecemasan dan Kemampuan siswa dalam Menyelesaikan Masalah Matematika. Jurnal Pendidikan Informatika Dan Sains, 7(1), 28-41. http://dx.doi.org/10.31571/saintek.v7i1.766

Sriyana, S., \& Winarso, W. (2018). Perilaku Belajar Efektif Terhadap Kemampuan Kognitif Psikomotorik Siswa Dalam Pembelajaran Matematika. IndoMath: Indonesia Mathematics Education, 1(2), 77-92. https://doi.org/10.30738/indomath.v1i2.2548

Sugiatno, Priyatno, D., \& Riyanti, S. (2020). Tingkat dan Faktor Kecemasan Matematika pada siswa Menengah Pertama. Jurnal Pendidikan Dan Pembelajaran Khatulistiwa, 6(10), 1 12. Retrieved from https://jurnal.untan.ac.id/index.php/jpdpb/article/view/22105

Sumartini, T. S. (2016). Peningkatan kemampuan pemecahan masalah matematis siswa melalui pembelajaran berbasis masalah. Mosharafa: Jurnal Pendidikan Matematika, 5(2), 148158. https://doi.org/10.31980/mosharafa.v5i2.270

Sutame, K., Hapsari, M. J., \& Jabar, A. (2012). Mereduksi Mathematics Anxiety dan Menyuburkan Problem SolvingAbility dengan Pendekatan Problem Posing. Lentera Jurnal Pendidikan, 7(2), 49-61.

Tarzimah, Tambychika \& Meerah, T. S. M. (2010). Students Difficulties In Mathematics Problem Solving:What do they say? International Conference on Mathematics Education Research, 
8, 142-151. https://doi.org/10.1016/j.sbspro.2010.12.020

Tresa, I. G. (2011). Efektivitas Konseling Behavioral dengan Teknik Desensitisasi Sistematis untuk Mereduksi Kecemasan Menghadapi Ujian: Studi Eksperimen pada Siswa Kelas X SMA Negeri 2 Singaraja Tahun Ajaran 2010/2011. (Doctoral dissertation, Universitas pendidikan indonesia). Retrieved from http://repository.upi.edu/9721/

Wenzel, A., Dobson, K. S., \& Hays, P. A. (2016). Cognitive behavioral therapy techniques and strategies. American Psychological Association.

Winarso, W., \& Haqq, A. A. (2019). Psichological disposition of student; Mathematics anxiety vesus happines learning on the level education. International Journal of Trends in Mathematics Education Research, 2(1), 19. https://doi.org/10.33122/ijtmer.v2i1.32

Winarso, W., \& Yuliyanti, D. D. (2017). Pengembangan Bahan Ajar Matematika Berbentuk Leaflet Berbasis Kemampuan Kognitif Siswa Berdasarkan Teori Bruner. JIPM (Jurnal Ilmiah Pendidikan Matematika), 6(1), 11-24. http://doi.org/10.25273/jipm.v6i1.1287

Wolpe, J. (1964). The Systematic Desensitization Treatment of Neuroses. In Experiments in Behaviour Therapy (pp. 21-39). https://doi.org/10.1016/B978-0-08-010054-8.50006-X

Yáñez-Marquina, L., \& Villardón-Gallego, L. (2017). Math anxiety, a hierarchical construct: Development and validation of the Scale for Assessing Math Anxiety in Secondary education. Ansiedad y Estrés, 23(2-3), 59-65. https://doi.org/10.1016/j.anyes.2017.10.001

Zettle, R. D. (2003). Acceptance and commitment therapy (ACT) vs. systematic desensitization in treatment of mathematics anxiety. The psychological record,53(2), 197-215. https://doi.org/10.1007/BF03395440 